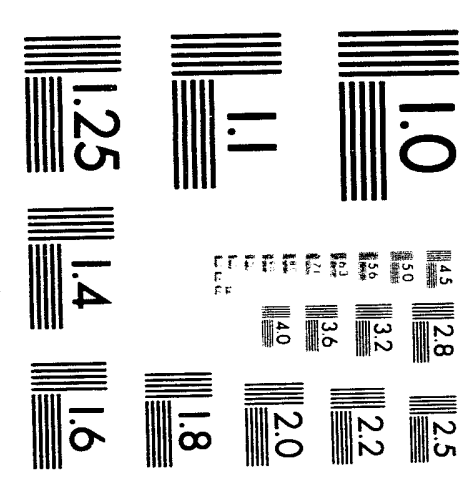



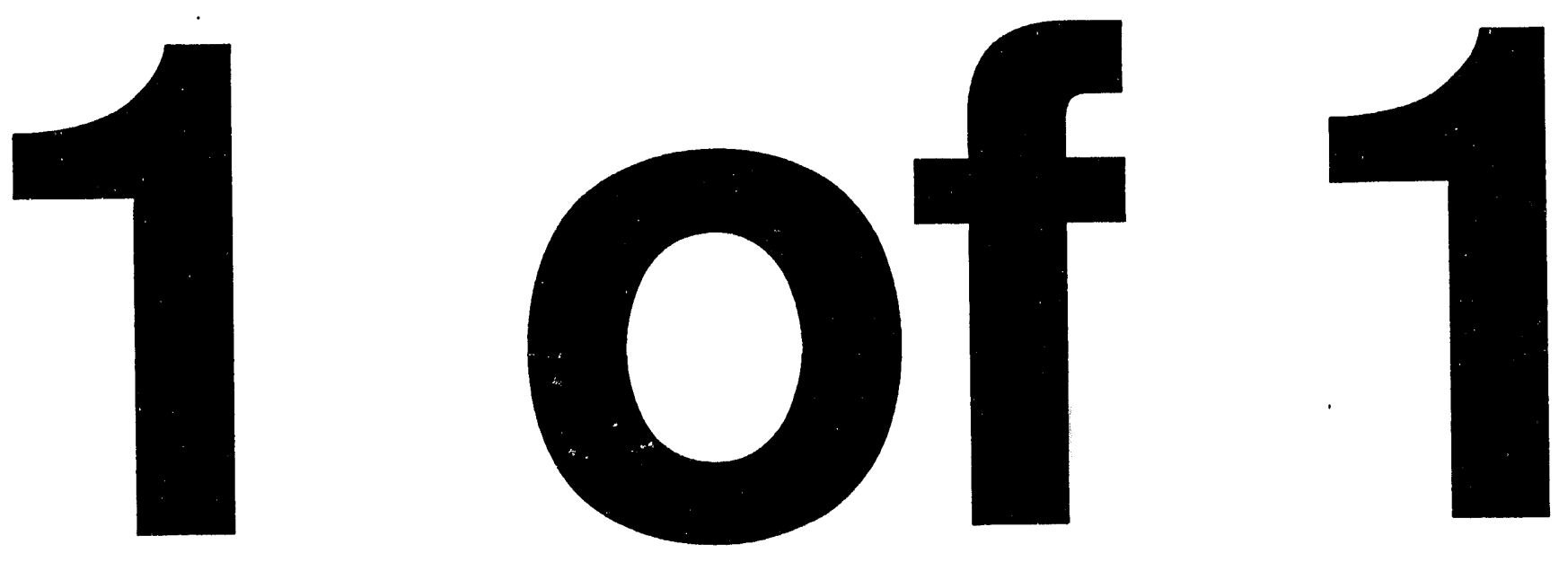
SAND93-8012

UC-402

Unlimited Release

Printed August 1993

\title{
NONSTRUCTURAL SEISMIC RESTRAINT GUIDELINES
}

Deana M. Butler, Robert H. Czapinski, Michael J. Firneno, Harold C. Feemster, Neal R. Fornaciari, Robert G. Hillaire, Robert L. Kinzel, Dave Kirk, Terry T. McMahon

Sandia National Laboratories/California

\begin{abstract}
The Nonstructural Seismic Restraint Guidelines provide general information about how to secure or restrain items (such as material, equipment, furniture, and tools) in order to prevent injury and property, environmental, or programmatic damage during or following an earthquake. All SNL sites may experience earthquakes of magnitude 6.0 or higher on the Richter scale. Therefore, these guidelines are written for all SNL sites.
\end{abstract}

\section{MASTER}




\section{CONTENTS}

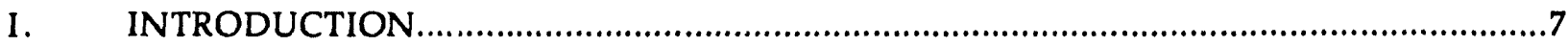

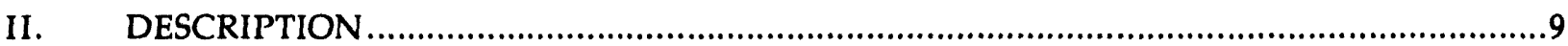

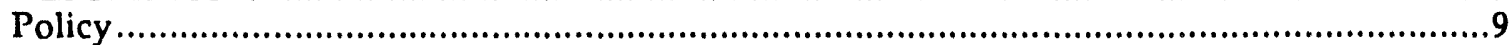

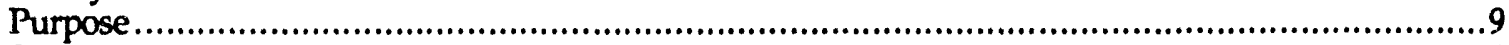

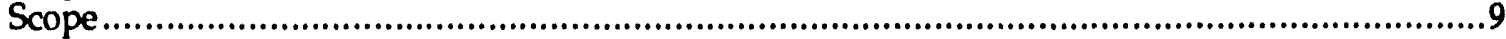

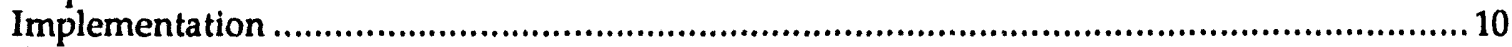

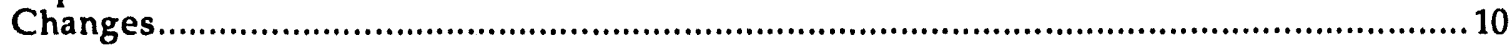

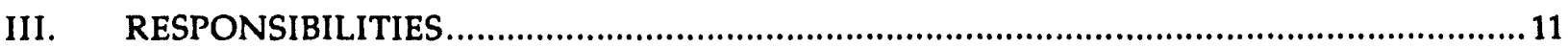

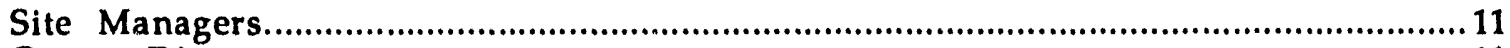

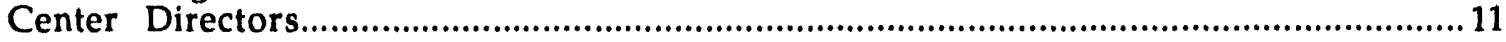

Department Managers............................................................................................................ 11

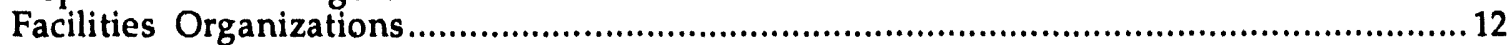

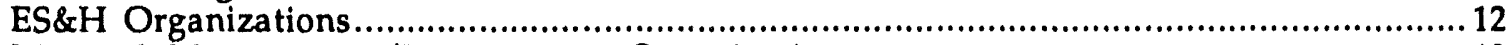

Material Management/Procurement Organizations................................................................ 13

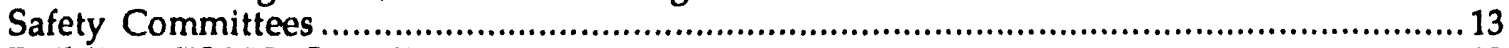

Building ES\&H Coordinators........................................................................................... 13

Key Department Personnel (Optional) .......................................................................... 14

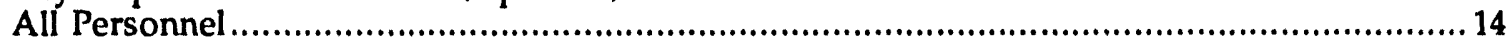

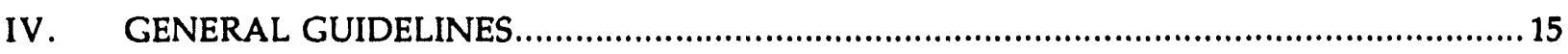

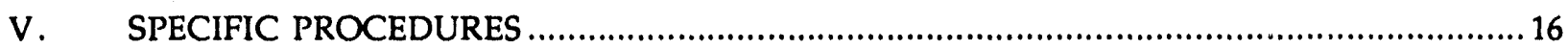

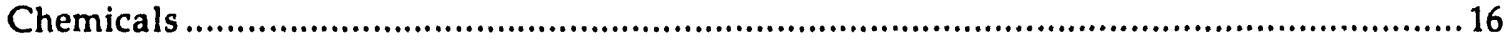

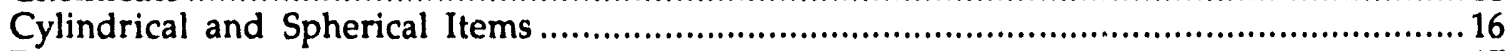

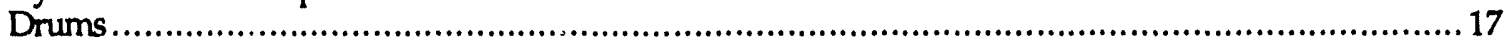

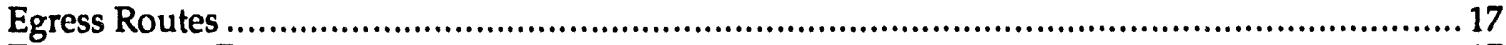

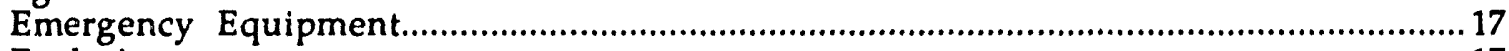

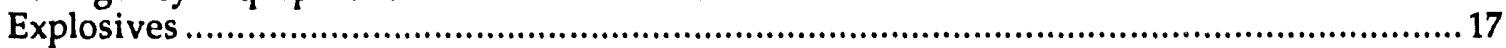

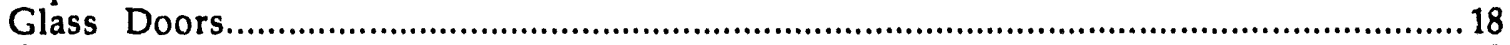

Glassware

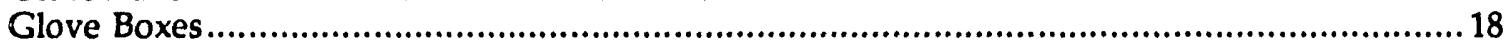

Hazardous Equipment (Potentially)............................................................................. 18

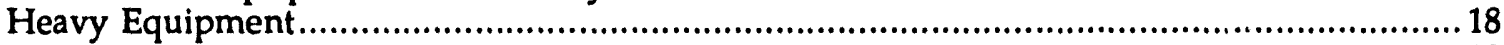

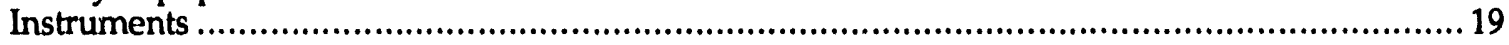

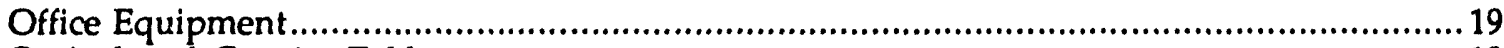

Optical and Granite Tables ........................................................................................... 19

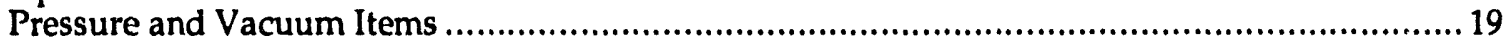

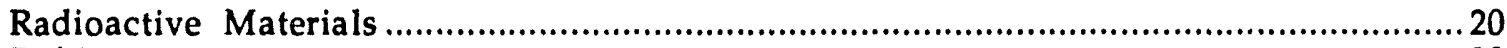

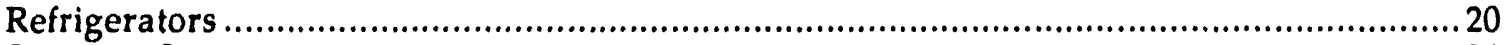

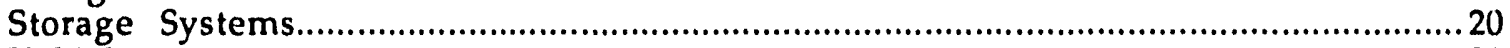

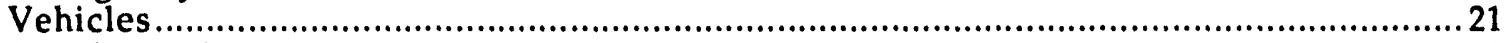

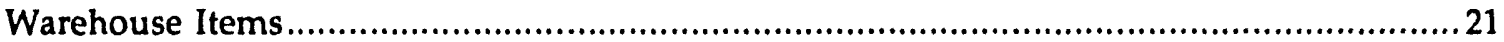

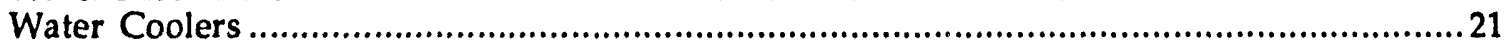

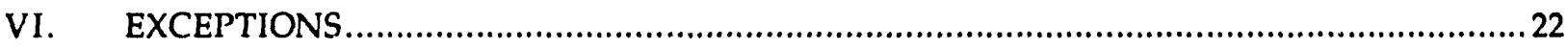

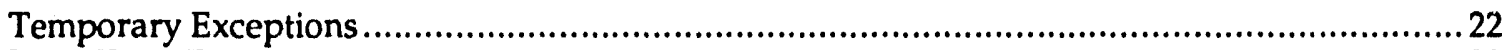

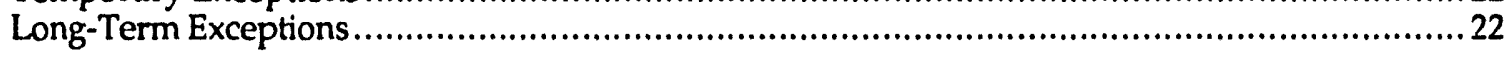

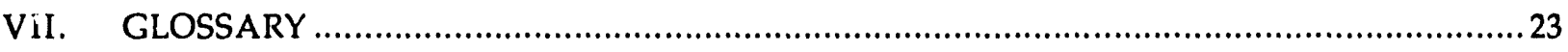

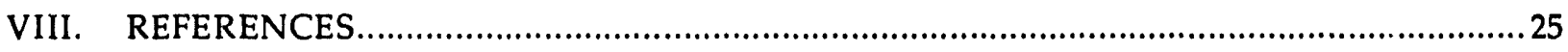

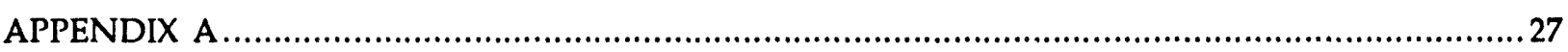

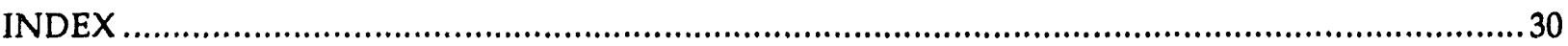




\section{INTRODUCTION}

The United States Geological Survey (USGS) indicates that all Sandia National Laboratories (SNL) sites may experience earthquakes of magnitude 6.0 or higher on the Richter scale. However, the ground movement and therefore, impact, may not be the same at each site due to differences in ground composition and structure.

The 1991 Uniform Building Code (UBC) rates the severity of seismic activity within the United States on a scale of 0 to 4,0 being the lowest rating (see Fig. 1). ${ }^{1}$ The category 2 rating is broken into two subgroups: $2 \mathrm{~A}$ and $2 \mathrm{~B}$. The $2 \mathrm{~A}$ rating is $200 \%$ of the 1 rating, and the $2 B$ rating is $267 \%$ of the 1 rating. Figure 2 shows the ratings of all SNL sites.

The probability of injury or damage is different at each of SNL's four sites (New Mexico, California, Nevada, and Hawaii). Therefore, each site manager is to take a graded approach to implementing the Nonstructural Seismic Restraint Guidelines at each site, commensurate with the potential for injury or damage.

These seismic guidelines ensure that SNL complies with DOE Order 5480.28, Natural Phenomena Hazards Mitigation. ${ }^{2}$ It also describes procedures that are easy and inexpensive to implement, yet which offer substantial benefits.

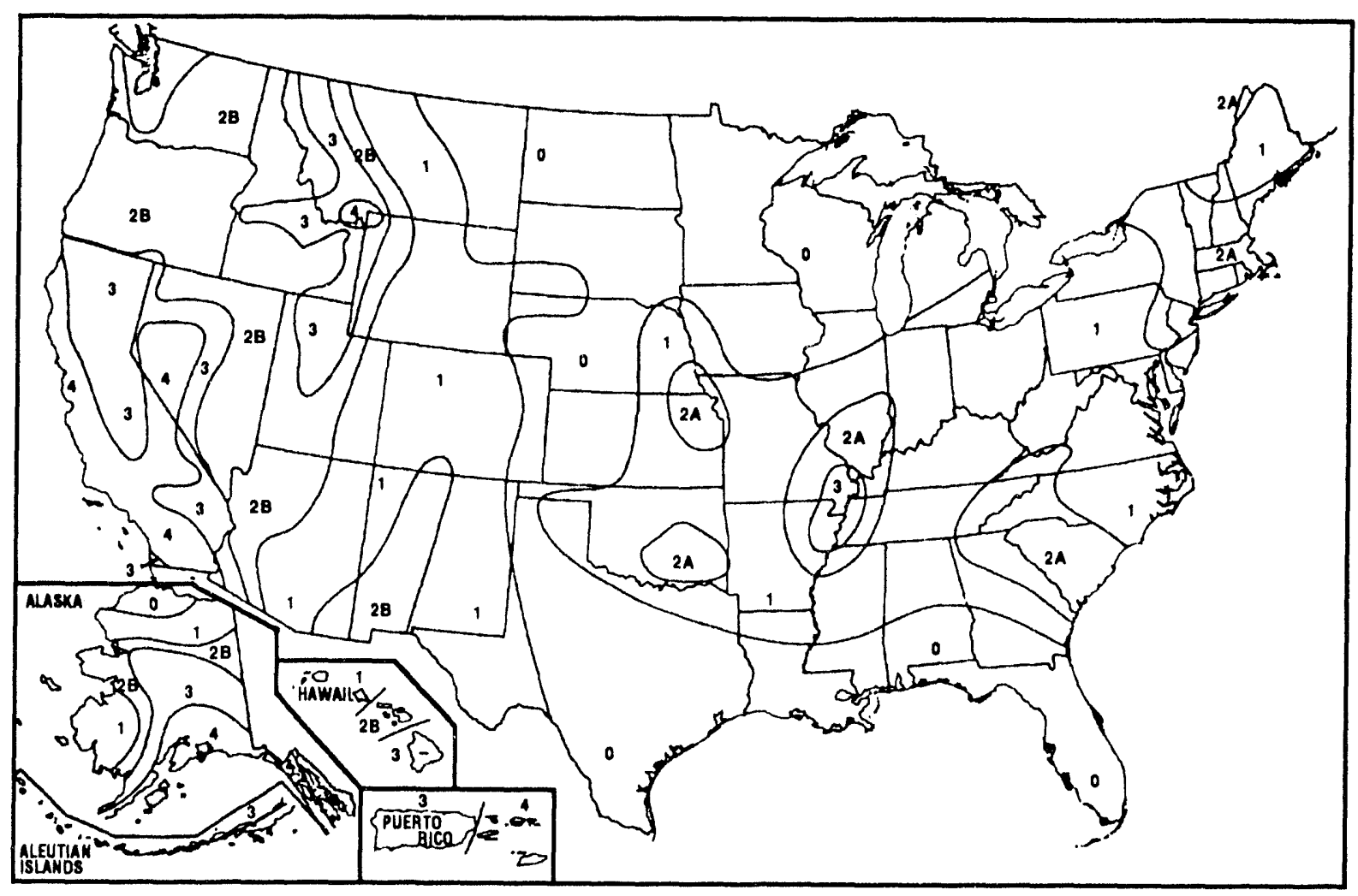

Figure 1. Seismic zone map of the United States. 


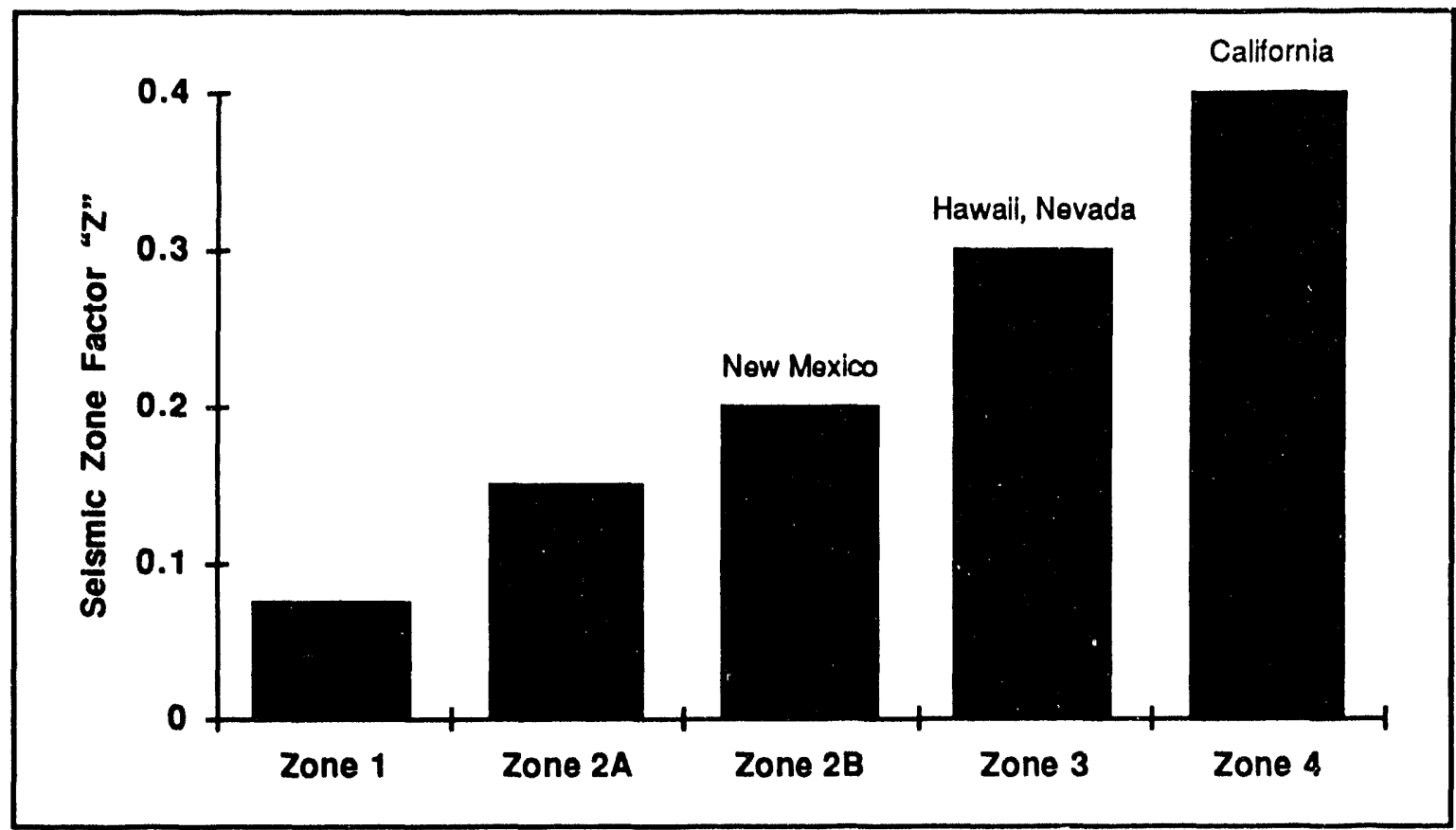

Figure 2. Uniform Building Code seismic rating of each SNL site. 


\section{DESCRIPTION}

\section{Policy}

SNL's policy is to secure or restrain from movement any items (such as materials, equipment, furniture, or tools) that may injure personnel, block egress, or cause substantial property, environmental, or programmatic damage during or following an earthquake.

\section{Purpose}

The purpose of this document is to accomplish the following goals:

- Establish guidelines for implementing procedures to reduce:

- injury,

- environmental impact,

- loss of valuable property, equipment, or services,

- programmatic damage,

- the risk of blocking exits, which may impede building evacuation or reentry for rescue, and

- the amount of time and resources required to resume normal activities after an earthquake;

- Establish comprehensive seismic planning and implementation standards and guidelines;

- Take into consideration the potential level of seismic damage at each SNL site, thereby helping site managers determine the right approach to seismic restraints at their sites; and

- Provide line personnel restraining methods to follow, using seismicrelated products available through Stores (see Appendix A).

\section{Scope}

This document encompasses restraining and securing from movement any items that may fall or be displaced or propelled during an earthquake and thereby may injure personnel, block egress, or cause substantial property, environmental, or programmatic damage.

These guidelines do not address code and design requirements, structural issues, or emergency preparedness procedures, other than to recognize that they complement the information provided herein. 


\section{Implementation}

SNL's Nonstructural Seismic Restraint Guidelines will be implemented in two phases.

\section{Phase I}

In Phase I, safety committees, building ES\&H coordinators, and facilities, ES\&H, and key department personnel will be trained in the proper selection, application, and installation of seismic-related products available through Stores (see Appendix A).

Line personnel will install seismic-related products available through Stores, according to the guidelines in this document.

The facilities organizations at each site will continue to secure items that may injure personnel, block egress, or cause substantial property, environmental, or programmatic damage during or following an earthquake. The Facilities Planning/Construction Management Department, 8611, will write the Seismic Restraints Manual to describe the appropriate materials and methods for securing such items. This document is to be completed by December 1, 1993.

\section{Phase II}

In Phase II, the facilities organizations at each site wiil review secured or restrained items to ensure that the materials and methods used are in compliance with the Seismic Restraints Manual. Facilities personnel will remove unacceptable seismic restraints and install acceptable restraints.

\section{Changes}

As SNL develops more effective methods of mitigating hazards while implementing this document, these guidelines will continue to evolve. Proposed changes may be submitted to the identified program owner for subsequent presentation to the appropriate ES\&H and facilities organizations, and to the Line Implementation Working Group (LIWG). 


\section{RESPONSIBILITIES}

\section{Site Managers}

Site managers are responsible for taking a graded approach to selecting the appropriate guidelines to be implemented at their sites.

\section{Center Directors}

Center directors are responsible for the following:

- Evaluating seismic safety needs for their personnel, programs, and facilities;

- Prioritizing implementation of these guidelines (making sure the potentially most hazardous items are secured or restrained first); and

- Ensuring implementation in a reasonable and timely manner.

\section{Department Managers}

Department managers are responsible for the following:

- Performing and documenting seismic hazards evaluations;

- Identifying items that require securing or restraining, making sure that they are still required by the department and are located so as to minimize the effort required to secure them without reducing their utility;

- Prioritizing securing and restraining activities;

- Ensuring guideline implementation in a reasonable and timely manner;

- Requesting and ensuring completion and documentation of corrective actions;

- Designating key department personnel to attend training in the proper selection, application, and installation of seismic-related products available through Stores (see Appendix A);

- Ensuring the use of seismic-related products available through Stores, where appropriate;

- Considering seismic safety when procuring equipment;

- Providing a budget for the facilities organizations to develop nonstandard methods for securing items on a case-by-case basis;

- Ensuring seismic safety issues are addressed when department personnel are developing and conducting operations and experiments; and

- Ensuring the control of temporary storage of unrestrained items (see "Exceptions," page 22).

\footnotetext{
"This responsibility is optional; see "Responsibilities-Key Department Personnel," page 14.

** Items that require the use of tools, access to confined spaces, or exposure to hazards are not to be secured by line personnel-see "Facilities Organizations," page 12. This restriction is intended to prevent injury due to improper use of tools, materials, or methods.
} 


\section{Facilities Organizations}

The facilities organizations are responsible for the following:

- Securing items that require the use of tools, access to confined spaces, or exposure to hazards, according to the Seismic Restraints Manual;

- Developing and documenting appropriate standard and nonstandard methods and materials for securing items;

- Evaluating and approving (jointly with the appropriate ES\&H organization) the seismic-related products available through Stores (see Appendix A);

- Ensuring guideline implementation in a reasonable and timely manner;

- Making sure that the Seismic Restraints Manual project owner and designated alternate attend training in the proper selection, application, and installation of seismic-related products available through Stores;

- Providing seismic safety guidance and hazards evaluations, when requested;

- Developing, documenting, and installing the products used to secure vending machines; and

- Assembling and maintaining an emergency facility inspection team that can determine the condition and hazards of structural and nonstructural items and utilities after an earthquake.

\section{ES\&H Organizations}

The ES\&H organizations are responsible for the following:

- Providing seismic safety guidance and hazards evaluations, when requested;

- Reviewing Standard Operating Procedures (SOPs) to determine if seismic concerns are adequately addressed;

- Consulting with facilities organizations on seismic safety for facility design and use plans;

- Evaluating and approving (jointly with the appropriate facilities organizations) the seismic-related products available through Stores (see Appendix A);

- Developing and presenting training in the proper selection, application, and installation of the seismic-related products available through Stores, to safety committees, ES\&H and facilities personnel, building ES\&H coordinators, and key department personnel; and

- Updating this document, as needed. 


\section{Material Management/Procurement Organizations}

The Material Management Department at SNL/California and the Procurement Department at SNL/New Mexico are responsible for ensuring the availability of a seismic-related products inventory, as approved by the appropriate facilities and ES\&H organizations, through Stores.

\section{Safety Committees}

Designated department or center safety committee members are responsible for the following:

- Attending training in the proper selection, application, and installation of seismic-related products available through Stores (see Appendix A);

- Providing guidance to center personnel as required;

- Obtaining guidance from ES\&H and facilities organizations, as needed;

- Helping install seismic-related products available through Stores; ${ }^{*}$ and

- Ensuring the review of seismic safety during normally scheduled, semiannual safety inspections to verify conformance to these guidelines.

\section{Building ES\&H Coordinators}

Building ES\&H coordinators, or designees, are responsible for the following:

- Attending training in the proper selection, application, and installation of seismic-related products available through Stores (see Appendix A);

- Ensuring that appropriate items in common areas of their buildings are secured; ${ }^{*}$ and

- Obtaining guidance from the ES\&H and facilities organizations, as needed.

*Items that require the use of tools, access to confined spaces, or exposure to hazards are not to be secured by safety committee members or building ES\&H coordinators-see "Facilities

Organizations," page 12. This restriction is intended to prevent injury due to improper use of tools, materials, or methods. 


\section{Key Department Personnel (Optional)}

Department managers may wish to designate key department personnel to accept responsibility for seismic safety, especially at remote sites or in areas with unusually sensitive, specialized, expensive, or hazardous items. If designated, these key department personnel are responsible for the following:

- Attending training in the proper selection, application, and installation of seismic-related products available through Stores (see Appendix A);

- Helping install seismic-related products available through Stores;

- Providing guidance to department personnel, as required; and

- Obtaining guidance from the ES\&H and facilities organizations, as needed.

\section{All Personnel}

All personnel at SNL sites are responsible for the following:

- Ensuring that their work environments comply with these guidelines at the level determined by their site manager (see "ResponsibilitiesSite Managers," page 11); and

- Identifying items that need to be secured when their work environments are reconfigured.

\footnotetext{
"Items that require the use of tools, access to confined spaces, or exposure to hazards are not to be secured by key department personnel-see "Facilities Organizations," page 12. This restriction is intended to prevent injury due to improper use of tools, materials, or methods.
} 


\section{GENERAL GUIDELINES}

The following procedures are required at all SNL sites:

- Restrain all items that can obstruct egress (such as materials, equipment, furniture, and tools) during or fllowing an earthquake;

- Position items to minimize potential for injury or damage, such as against a wall-if items cannot be so positioned, secure these items to the floor or to adjacent items for increased stability;

- Place the heaviest items in the lowest part of a storage system to lower its center of gravity as much as possible;

- Do not store unsecured items behind doors;

- Do not attach items to conduit or wiring troughs; and

- When leaving n:aintenance or construction areas, secure items (especially ladders) so that they cannot roll, fall, block egress, or cause injury or damage.

The following procedures are site-specific; site managers are responsible for determining which ones are required at their sites:

- Use seismic anchors and restraints available through Stores (see Appenoix A) or listed in the Seismic Restraints Manual;

- Securc any movable object that can strike or trap personnel or that can in any way expose people to life-threatening injuries;

- Do not store heavy items on top of storage systems (such as cabinets or bookcases) taller than 54 inches, unless the storage systems and all items on top are secured or restrained;

- Ensure that chemicals or wash solutions are contained so that they do not splash or spill on the floor in an earthquake--this procedure is especially important if your work area has a floor drain;

- Equip all cabinets with positive-action (not magnetic) latches;

- Restrain unsecured items that could fall in an earthquake, such as bulletin boards, plants, pictures, wall hangings, or other heavy items stored above personnel; you may use Velcro, double-stick tape, approved restraining products available from Stores, or other simple methods, as appropriate; and

- Avoid using elastic restraint cords (i.e., Bungee cords) because the hooks are potentially dangerous.

An additional consideration at the California site is a gas cutoff valve, which is on the main PG\&E line running into the site. It shuts off gas to the site in an earthquake measuring 4.5 or greater on the Richter scale. Be sure to consider the impact of gas cutoff on experiments and operations when planning and implementing your organization's seismic safety procedures. 


\section{SPECIFIC PROCEDURES}

\section{Chemicals}

All SNL sites:"

- Keep all cabinet doors and drawers closed when not in use; and

- Use unbreakable containers for chemicals, whenever possible.

Site-specific:"

- Do not stack chemical containers more than two high;

- To prevent items from falling, make sure all open shelves and shelves with glass doors have raised lips, bars, or other means of restraint at their edges;

- Secure all chemical storage cabinets taller than 54 inches to a wall, the floor, or adjacent items;

- Secure all flammable cabinets according to fire protection guidelines so as not to reduce their integrity;

- Ensure that all storage systems used can maintain their structural integrity and containment during and following an earthquake;

- Segregate chemicals by hazard classification;

- Store liquid chemicals in unbreakable secondary containment;

- Secure all refrigerators that contain chemicals; and

- Make sure that all cabinets are equipped with positive-action (not magnetic) latches.

\section{Cylindrical and Spherical Items}

Cylindrical and spherical items include projectiles, bar stock, and tanks.

All SNL sites:

- Secure cylindrical or spherical items with sand bags, shot bags, chocks, straps, or cradles designed to prevent rolling; and

- Lower the center of gravity of the items as much as possible.

See also "Pressure and Vacuum Items," page 19.

\footnotetext{
"These procedures are required at all SNL sites.

** Site managers are responsible for determining which procedures are required at their sites. 


\section{Drums}

Drums include carboys and cubitainers.

All SNL sites:

- Store stacked drums as close to the floor as possible.

Site-specific:

- If empty 55-gallon drums are stacked, band each drum to its own pallet and stack only two high; and

- Stack drums containing chemicals only if they hold less than 55 gallons and only two high.

\section{Egress Routes}

All SNL sites:

- Arrange and restrain items so as to preserve an unobstructed corridor or egress during and following an earthquake;

- Make sure that all storage systems with drawers or doors in egress routes have positive-action latches to prevent their opening during an earthquake;

- Do not locate open-shelf storage systems in egress routes, unless the items on the shelves are restrained; and

- Do not store unsecured items behind doors.

\section{Emergency Equipment}

All SNL sites:

- Restrain all emergency equipment, including batteries, communications equipment, medical equipment, and power-switching equipment, as appropriate.

\section{Explosives}

All SNL sites (all explosives users, test areas, and storage facilities):

- Explosives storage systems must conform to the DOE Explosives Manual, which states, "Explosives and explosives components in storage shall be safely and securely positioned. If explosive containers must be stacked, they shall be placed in stable arrays." ${ }^{\prime 3}$ 


\section{Glass Doors}

All SNL sites:

- When glass doors on storage systems need to be replaced, use reinforced, laminated glass or nonglass products; and

- When ordering new storage systems with glass doors, order systems with either reinforced, laminated glass or nonglass doors.

\section{Glassware}

All SNL sites:

- Buy products in nonglass containers whenever possible; and

- Use unbreakable containers, whenever possible.

Site-specific:

- Use protective material (such as plastic webbing) over glassware, if practical, to reduce the risk of fragmentation in an earthquake.

\section{Glove Boxes}

Site-specific:

- Restrain glove boxes, their contents, and objects placed on them.

\section{Hazardous Equipment (Potentially)}

All SNL sites:

- Make sure potentially hazardous equipment (such as lathes, drills, presses, and generators) requires manual restart after a power outage to prevent an automatic restart when power is restored.

\section{Heavy Equipment}

All SNL sites:

- Contact the appropriate facilities organizations at your site to secure heavy equipment (such as spectrometers, electron microscopes, lathes, drills, and presses). 


\section{Instruments}

Site-specific:

- Whenever practical, restrain instruments (such as balances, ovens, microscopes, and scales) with seismic-related products available through Stores (see Appendix A).

\section{Office Equipment}

Site-specific:

- Secure the following types of office equipment: coffee pots, computers and printers, copy machines (table-top models), facsimile machines, microwave ovens, and typewriters.

\section{Optical and Granite Tables}

Some optical and granite table tops may not be secured to the legs and can fall during an earthquake. Optical tables have also been known to "walk" during seismic activity.

All SNL sites:

- Secure equipment on optical or granite tables as well as practical.

\section{Pressure and Vacuum Items}

Pressure and vacuum items include welding tanks and gas cylinders. The Pressure Safety Committee will incorporate these guidelines into the Pressure Safety Manual. ${ }^{4}$

All SNL sites:

- Secure gas cylinders with a chain or a strap located slightly above the center of the cylinder;

- Restrain 160-liter dewars; and

- Always keep a protective cap or cover on a gas cylinder unless it is in use.

Site-specific:

- Two chains or straps are recommended on all cylinders taller than 48 inches; place the straps approximately $1 / 3$ and $2 / 3$ up the cylinder height; and

- Secure welding carts, when not in use, to a wall or floor with a chain or strap.

See also "Cylindrical and Spherical Items," page 16. 


\section{Radioactive Materials}

Radioactive storage systems and shielding must be able to maintain their structural integrity and containment during and following an earthquake.

Site-specific (all radioactive users, test areas, and storage facilities):

- Ensure that all open shelves and shelves with glass doors have raised lips, bars, or other means of restraint at their edges;

- Make sure that all cabinets are equipped with positive-action (not magnetic) latches; and

- Secure all refrigerators that contain radioactive materials.

\section{Refrigerators}

All SNL sites:

- Secure full-size refrigerators that are located in high traffic areas or that can block egress.

Site-specific:

- Secure all refrigerators that contain chemicals or radioactive materials; and

- Secure table-top refrigerators.

\section{Storage Systems}

Storage systems include bookcases, cabinets, carts, equipment racks, filing cabinets, lockers, tool boxes, Vidmar or similar cabinets, and safes.

All SNL sites:

- Locate storage systems and stored items so as to reduce potential injury or damage;

- Place the heaviest items in the lowest part of a storage system taller than 54 inches to lower its center of gravity as much as possible;

- Open only one drawer in a storage system at a time; and

- Close and secure drawers immediately after each use.

Site-specific:

- Lower, remove, or secure to a wall, the floor, or adjacent objects all storage systems taller than 54 inches;

- If applicable, remove the legs of any storage system taller than 48 inches or secure the item;

- Secure items on open shelves higher than 54 inches off the floor with seismic-related products available through Stores (see Appendix A);

- Secure multiple rows of shelves (e.g., libraries, vaults, and file rooms) to walls or floors, and brace all units together across the top to increase stability; and 
- If Vidmar or similar cabinets do not have thiumb latches on each drawer, keep the cabinet locked, except when a drawer is open. (Note: the Model Shop, 8284-1, can retrofit these cabinets with locks, if necessary.)

\section{Items with Wheels and Brakes}

- If an item does not need to remain portable, either remove its wheels or apply its brakes and secure it to the wall, floor, or similar units, only if it can be secured without substantially reducing its utility; and

- If an item cannot be secured or needs to remain portable, do not apply its brakes and if practical, tether it above its center of gravity when not in use to restrict its movement.

\section{Vehicles}

Vehicles include cars, trucks, carts, bicycles, forklifts, and tractors. At all SNL sites, these items must be parked out of egress routes.

\section{Warehouse Items}

Site-specific:

- Locate freestanding items taller than 54 inches away from egress routes and secure them to minimize the danger of their falling or tipping into aisles;

- Band items stored higher than 54 inches to pallets;

- Restrain large items stored on shelves above 54 inches;

- Band together items on pallets if they are stacked;

- Do not stack pallets more than two high;

- Store raw materials (e.g., bar stock, wood, and pipe) in racks with shelves that are angled down toward the back of the rack; and

- Mark the floors to delineate the safest traffic areas in warehouses.

\section{Water Coolers}

Site-specific:

- Secure both bottles and dispensers if they can block egress during or following an earthquake. 


\section{EXCEPTIONS}

\section{Temporary Exceptions}

Departments may store unrestrained electronic racks and other portable equipment temporarily. Department managers are responsible for assuring the control of temporarily stored items, ensuring that the following requirements are met:

- The items are arranged and restrained to preserve an unobstructed corridor or egress during and following an earthquake; and

- The items are located so as to minimize the potential for injury or damage.

Items that are not usable when restrained, such as dumpsters, are not required to be secured. Instead, these items must be located away from normal traffic areas.

\section{Long-Term Exceptions}

Exceptions to these guidelines are permitted at any SNL site if all the following requirements are met:

- The responsible department manager validates the need for the exception;

- An alternative method (or methods) for mitigating hazards is (or are) developed and documented;

- The appropriate facilities and ES\&H organizations approve the alternative hazards mitigation method(s);

- The department submits copies of the exceptions to the appropriate facilities and ES\&H organizations;

- The department manager documents exceptions in the Management Assurance Notebook (MAN); and

- The department manager reviews exceptions at least annually. 


\section{GLOSSARY}

\section{Common Area}

ES\&H

Egress

Facilities Organizations

Graded Approach

Key Department Personnel

LIWG

Portable Equipment

Restrain

Secure

Seismic
Public or commonly used spaces (e.g., conference rooms, lobbies, stairwells, and hallways), unless the responsibility for one of these spaces is assigned to a specific person or organization.

Environment, safety, and health. The SNL organizations responsible for ES\&H are Centers 7700 and 8600.

A place or means of exiting.

Any of the SNL organizations responsible for maintenance, operations, facilities, planning, or modifications. They are Centers 7800 and 8600 .

Flexibility in complying with these guidelines. Site managers use a graded approach to determine which guidelines to implement at their sites, according to the potential for injury or damage during or following an earhquake. (See "Responsibilities-Site Managers," page 11.)

SNL employees or contractors assigned by department managers to be responsible for restraining and securing items that could cause injury or damage in an earthquake. (See "Responsibilities-Key Department Personnel," page 14.)

Line Implementation Working Group. This group is the principal communication link between line personnel and the ES\&H support organizations.

Items that personnel move to perform tasks, such as equipment or supply carts, equipment racks, welding carts, tool boxes, and cylinder carts.

To limit the movement of an object, yet allow some movement for ease of use.

To restrict the movement of an item by fastening it to a stationary object, such as a wall, floor, or other permanent structure, or to other similar items.

NOTE: "Restrain" and "secure" are used interchangeably in these guidelines to allow users to choose the method of securing or restraining items, in most instances.

Related to an earthquake. 
Seismic-Related Products

Stores
Commercial items available in Stores to restrain or secure objects during an earthquake. (See Appendix A.)

SNL department or service where personnel can order commonly used supplies. In these guidelines, "Stores" includes the Just-In-Time system in New Mexico. 


\section{REFERENCES}

1. State of California, Uniform Building Code (1991).

2. U. S. DOE, Order 5480.28, Natural Phenomena Hazards Mitigation (January 15, 1993).

3. U. S. DOE, Explosives Manual, Chapter II, Section 17.2.c, DOE/EV/06194 (October 1991).

4. U. S. DOE, Sandia National Laboratories, Pressure Safety Manual, MN471000 (November 2, 1992). 


\section{APPENDIX A}

\section{SEISMIC-RELATED PRODUCTS AVAILABLE THROUGH STORES}

\section{SAFETY, EARTHQUAKE PREPAREDNESS}

\section{FASTENERS}

VersaBLOCK, fasteners, for stacking printers etc., molded of high strength nylon, lifetime durability, 2" $\times 2^{\prime \prime}$, includes instructions and alcohol cleaning pads, grey (4 Blocks/PG). UNIT OF ISSUE: PG STOCK NO. 602024

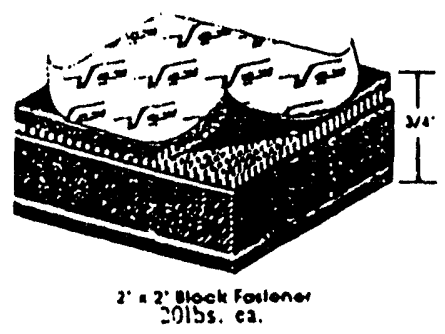

VersaBRACE, fasteners, for all types of equipment, bend for desired shape, molded of high-strength nylon, superior flexibility without breaking, includes instructions and alcohol cluaning pads, grey (4 Braces/PG). UNIT OF ISSUE: PG

\section{SIZE}

$2^{n}$ (small to medium objects)

$3^{\prime \prime}$ (medium to large objects)
STOCKNO.

602022

602023

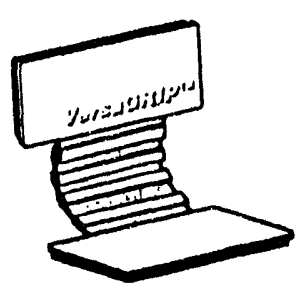

VersaTETHER, adjustable fasteners, to minimize movement of small items (keyboards, monitors, lab instruments, etc.), molded of high-strength nylon, includes instructions and alcohol pads, grey.

UNIT OF ISSUE: EA

\section{SIZE}

22" (maximum)

42" (maximum)
STOCKNO

602025

602026

VersaTETHER, extension strap, 22", for use with VersaTETHER fasteners, Stock No.'s, $602025 \& 602026$.

UNIT OF ISSUE: EA

STOCK NO. 602033 NOTE: Avallable approximately 9/15/93. 


\section{FASTENERS (cont.)}

VersaTETHER, strap, for Laser/Optical tables, secures items by bolting straps to the tables over and around equipment. Has 2 grommets on each end on 1 " centers. Equipped with a "quick-release" latch that allows easy moving of equipment. UNIT OF ISSUE: EA STOCK NO. 602034 NOTE: Avallable approximately 9/15/93.

Snap-Trac Fastening Plate, kit contains (1) $1^{n} \times 6^{n}$ base plate with (3) adjustment slots. For use with Stock No.'s, 602035 \& 602 036, includes instructions and alcohol cleaning pads.

UNIT OF ISSUE: EA

STOCK NO. 602037

\section{NOTE: Available approximately 9/15/93.}

Snap-Trac Straps 3-M VHB adhesive kit contains (2) 24 " straps with a snap hook at one end to attach to a base plate (Stock No. 602 037) and 3-M VHB adhesive plates on the other end for attaching to flat surfaces of equipment. Straps are fully adjustable with quick-release buckle, includes instructions and alcohol cleaning pads.

UNIT OF ISSUE: EA

STOCK NO. 602035 NOTE: Avallable approximately 9/15/93.

Snap-Trac Straps with Velcro fasteners. Kit contains (2) 24" straps with a hook at one end to attach to base plate (Stock No. 602 037) and adhesive hacked Velcro fasteners on the other end to attach to irregular or curved equipment. Straps are fully adjustable with quick-release buckle, includes instructions and alcohol cleaning pads.

UNIT OF ISSUE: EA

STOCK NO. 602036 NOTE: Avallable approximately 9/15/93.

\section{MATS}

MATS, QuakeMat, non-skid pads for tables/counters to keep items (calculators, phones, lab instruments, computer equipment) from sliding during earthquakes, grey. UNIT OF ISSUE: EA

$\begin{array}{cc}\text { SIZE } & \text { STOCK NO } \\ 5^{\prime \prime} \times 18^{\prime \prime} & 602031 \\ 10^{\prime \prime} \times 12^{\prime \prime} & 602030 \\ 18^{\prime \prime} \times 21^{\prime \prime} & 602029\end{array}$




\section{RETENTION BAR}

RETENTION BAR, Book-KEEPER, slides down over books, binders, documents, etc., to keep them from falling off shelves during earthquakes, attaches with adhesive, includes instructions and alcohol cleaning pads, (adjustable 25" - 39")

UNIT OF ISSUE: EA

STOCK NO. 602032

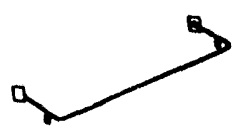

\section{TAPE}

TAPE, Quake Relocation, for relocating VersaGRIP items or replacement when Velcro becomes worn, includes both parts of the Velcro. (36"/RL).

UNIT OF ISSUE: RL

STOCK NO. 602027

TAPE, Quake, adhesive on both sides, used to hold items down (plants, pictures, etc.), cut to length, includes instructions and alcohol pads. (36"/RL)

UNIT OF ISSUE: RL

STOCK NO. 602028 


\section{INDEX}

Balances, 19

Bar Stock, 16, 21

Batteries, 17

Bicycles, 21

Bookcases, 15, 20

Brakes, 21

Bulletin Boards, 15

Bungee Cords, 15

Cabinets, 15, 16, 20

Carboys, 17

Cars, 21

Carts, 20, 21

Chemicals, 15, 16

Coffee Pots, 19

Communications Equipment, 17

Computers, 19

Conduit, 15

Copy Machines, 19

Cubitainers, 17

Cylindrical Items, 16

Dewars, 19

Doors, 15, 16, 17, 18

Drawers, 16, 17, 20

Drills, 18

Drums, 17

Dumpsters, 22

Egress, 9, 15, 17, 20, 21, 22

Electron Microscopes, 18

Electronic Racks, 22

Emergency Equipment, 17

Equipment, 9, 15

Equipment Racks, 20

Explosives, 17

Facsimile Machines, 19

File Rooms, 21

Filing Cabinets, 20

Flammable Cabinets, 16

Forklifts, 21

Furniture, 9, 15

Gas Cylinders, 19

Glass Doors, 16, 18, 20

Glassware, 18

Glove Boxes, 18

Granite Tables, 19

Hazardous Equipment, 18

Heavy Equipment, 18

Instruments, 19

Items with Wheels and Brakes, 21

Ladders, 15

Latches, 15, 16, 17, 20, 21

Lathes, 18

Libraries, 21

Lockers, 20

Materials, 9, 15

Medical Equipment, 17
Microscopes, 19

Microwave Ovens, 19

Office Equipment, 19

Open Shelves, 16, 17, 20

Optical Tables, 19

Ovens, 19

Pallets, 17, 21

Pictures, 15

Pipe, 21

Plants, 15

Portable Equipment, 21, 22

Power-switching Equipment, 17

Presses, 18

Pressire and Vacuum Items, 19

Printers, 19

Projectiles, 16

Racks, 21

Radioactive Materials, 20

Refrigerators, 16, 20

Safes, 20

Scales, 19

Seismic Restraints Manual, 10, 12, 15

Spectrometers, 18

Spherical Items, 16

Storage Systems, 15, 16, 17, 18, 20

Tanks, 16

Tool Boxes, 20

Tools, 9, 15

Tractors, 21

Trucks, 21

Typewriters, 19

Vaults, 21

Vehicles, 21

Vending Machines, 12

Vidmar Cabinets, 20, 21

Wall Hangings, 15

Warehouse, 21

Wash Solutions, 15

Water Coolers, 21

Welding Tanks, 19

Wiring Troughs, 15

Wood, 21 


\section{INITIAL DISTRIBUTION}

\section{UNLIMITED RELEASE}

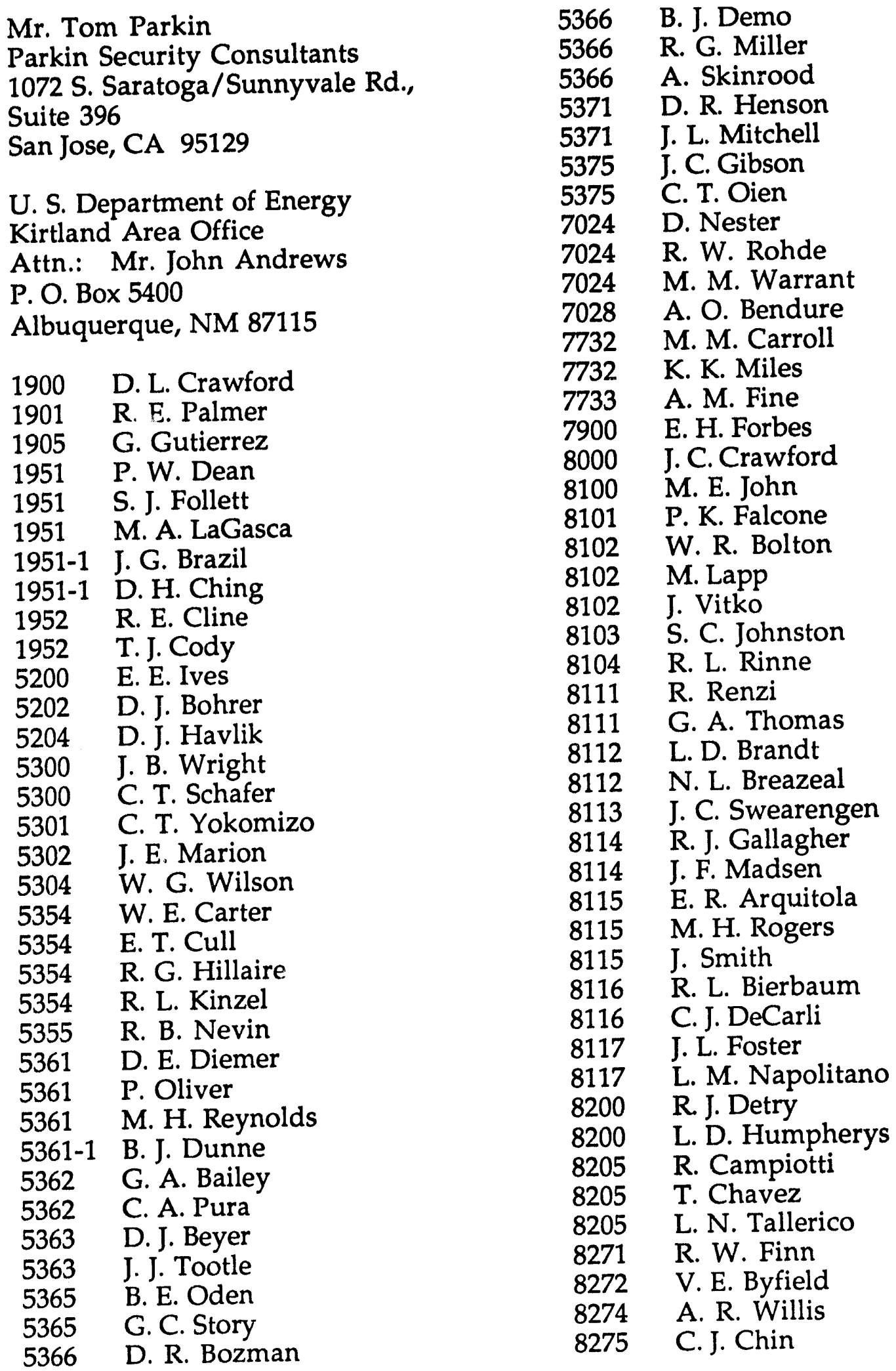




$\begin{array}{ll}8275 & \text { J. J. Petersen } \\ 8275 & \text { D. P. Van Dyke } \\ 8281 & \text { J. I. Bartel } \\ 8281 & \text { G. M. Giovacchini } \\ 8281 & \text { B. R. Wall } \\ 8283 & \text { J. A. Lamph } \\ 8283 & \text { M. P. Mikolajczyk } \\ 8283 & \text { P. D. Tamayo } \\ 8283-1 & \text { D. P. Green } \\ 8283-1 & \text { S. Ikebe } \\ 8284 & \text { B. E. Affeldt } \\ 8284-1 & \text { A. Cardiel } \\ 8284-1 & \text { J. A. Fordham } \\ 8284-1 & \text { J. A. Spoonemore } \\ 8300 & \text { W. J. McLean } \\ 8300 & \text { J. S. Meeks } \\ 8302 & \text { W. Bauer } \\ 8304 & \text { K. L. Wilson } \\ 8305 & \text { G. B. Drummond } \\ 8341 & \text { W. G. Wolfer } \\ 8342 & \text { R. H. Stulen } \\ 8342 & \text { R. J. Anderson } \\ 8347 & \text { W. L. Chrisman } \\ 8347 & \text { D. H. Morse } \\ 8347 & \text { A. E. Pontau } \\ 8351 & \text { J. C. Laroco } \\ 8351 & \text { L. A. Rahn } \\ 8353 & \text { E. B. Bochenski } \\ 8353 & \text { M. W. Kimmel } \\ 8353 & \text { M. J. Jaska } \\ 8353 & \text { F. P. Tully } \\ 8355 & \text { G. A. Fisk } \\ 8361 & \text { T. T. Bramlette } \\ 8341 & \text { S. M. Ferko } \\ 8441 & \text { T. J. Sage } \\ 8361 & \text { D. R. Hardesty } \\ 8361 & \text { S. F. Rice } \\ 8361 & \text { A. J. Salmi } \\ 8362 & \text { R. W. Carling } \\ 8362 & \text { N. R. Fornaciari } \\ 8362 & \text { K. R. Hencken } \\ 8362 & \text { G. A. Hux } \\ 8362 & \text { R. R. Sepulveda } \\ 8362 & \text { S. R. Vosen } \\ \text { C. M. Hartwig } \\ \text { L. A. Hiles } \\ \text { C. L. Knapp } \\ \text { H. H. Hirano } \\ 84061\end{array}$

$\begin{array}{ll}8441 & \text { L. J. Seibel } \\ 8445 & \text { E. A. English } \\ 8446 & \text { A. J. West } \\ 8451 & \text { T. R. Harrison } \\ 8453 & \text { W. C. Peila } \\ 8453 & \text { G. L. Simpson } \\ 8453-1 & \text { V. C. Barr } \\ 8453-1 & \text { M. J. Firneno } \\ 8454 & \text { J. D. Berg } \\ 8454 & \text { A. L. Hull } \\ 8454 & \text { D. G. Stimmel } \\ 8455 & \text { M. A. Taylor } \\ 8476 & \text { P. G. Heppner } \\ 8476 & \text { J. L. VanDeVreugde } \\ 8500 & \text { P. E. Brewer } \\ 8501 & \text { M. A. Pound } \\ 8522 & \text { M. G. Gabbard } \\ 8522 & \text { P. N. Smith } \\ 8523 & \text { M. J. Connors } \\ 8523 & \text { R. C. Christman } \\ 8525 & \text { J. D. Foster } \\ 8525 & \text { R. L. Fugazzi } \\ 8526 & \text { B. G. Chamberlain } \\ 8526 & \text { D. E. Koker } \\ 8526 & \text { D. R. Williams } \\ 8527 & \text { D. F. Chuderewicz } \\ 8527 & \text { K. M. Dannis } \\ 8527 & \text { S. J. Walters } \\ 8531 & \text { D. R. Charlesworth } \\ 8531-1 & \text { P. G. Dominguez } \\ 8531-1 & \text { T. M. Smith } \\ 8532 & \text { D. D. Wagner } \\ 8532-1 & \text { T. C. Roudebush } \\ 8532-1 & \text { D. M. West } \\ 8533 & \text { T. L. Hebebrand } \\ 8533 & \text { S. L. Norris } \\ 8533 & \text { K. M. Mello } \\ 8533-1 & \text { K. E. Crider } \\ 8534 & \text { M. E. Rivenbark } \\ 8534 & \text { J. A. Wackerly } \\ 8535 & \text { C. A. Flores } \\ 8535 & \text { K. W. Gordon } \\ 8535 & \text { C. A. Richards } \\ 8535 & \text { R. H. Tucker } \\ 8536 & \text { S. C. Gray } \\ 8536 & \text { E. F. Diemer } \\ \text { L. A. West } & \text { T. M. Pope } \\ \text { C. M. Hinckley } \\ & \end{array}$

8441 L. J. Seibel

8446 A. J. West

8451 T. R. Harrison

8453 W. C. Pella

8453 G. L. Simpson

8453-1 M. J. Firneno

8454 J. D. Berg

8454 A. L. Hull

8454 D. G. Stimmel

8455 M. A. Taylor

8476 P. G. Heppner

8500 P. E. Brewer

8501 M. A. Pound

8522 M. G. Gabbard

8522 P. N. Smith

8523 M. J. Connors

8523 R. C. Christman

8525 J. D. Foster

8525 R. L. Fugazzi

8526 B. G. Chamberlain

8526 D. E. Koker

8526 D. R. Williams

8527

8527

8527

8531

8531-1 P. G. Dominguez

8531-1 T. M. Smith

8532 D. D. Wagner

8532-1 T. C. Roudebush

8532-1 D. M. West

8533 T. L. Hebebrand

8533 S. L. Norris

8533 K. M. Mello

8533-1 K. E. Crider

8534

8534

8535

8535

8535

8535

8536

8536

8602

8603
M. E. Rivenbark

J. A. Wackerly

lores

C. A. Richards

R. H. Tucker

S. C. Gray

L. A. West

C. M. Hinckley 


\begin{tabular}{|c|c|c|c|}
\hline $\begin{array}{l}8604 \\
8609 \\
8609 \\
8611 \\
8611 \\
8611 \\
8611 \\
8611 \\
8611 \\
8611 \\
8612 \\
8612 \\
8612 \\
8613 \\
8613 \\
8613 \\
8613-1 \\
8613-1 \\
8613-3 \\
8613-3 \\
8615 \\
8641 \\
8641 \\
8641 \\
8641 \\
8641 \\
8642 \\
8642 \\
8642 \\
8642 \\
8643 \\
8643 \\
8643 \\
8643 \\
8643 \\
8643 \\
8700 \\
8701 \\
8701 \\
8702 \\
8703 \\
8711 \\
8711 \\
8712 \\
8712 \\
8713 \\
8713 \\
8714 \\
8714\end{array}$ & $\begin{array}{l}\text { D. L. Mohrman } \\
\text { D. M. Abrahams } \\
\text { D. W. Putz } \\
\text { S. C. Carpenter } \\
\text { A. J. DuCharme } \\
\text { R. C. Garrett } \\
\text { N. L. Good } \\
\text { G. W. Shamber } \\
\text { H. B. Stryker } \\
\text { C. T. Taylor } \\
\text { L. D. Martinez } \\
\text { R. P. May } \\
\text { P. D. Vrieling } \\
\text { P. J. Canepa } \\
\text { D. Kirk } \\
\text { J. G. Pergrossi } \\
\text { G. D. Fisher } \\
\text { W. F. Seymour } \\
\text { T. C. Johnson } \\
\text { T. M. Marino } \\
\text { J. Ellison } \\
\text { R. H. Czapinski } \\
\text { J. A. Leon } \\
\text { D. E. Patrician } \\
\text { C. A. Seibel } \\
\text { D. A. Wright } \\
\text { D. M. Butler (100) } \\
\text { D. A. Nissen } \\
\text { P. M. O'Brion } \\
\text { K. K. Shepodd } \\
\text { F. W. Hart } \\
\text { P. A. Hatcher } \\
\text { S. N. Hines } \\
\text { T. T. McMahon } \\
\text { J. M. Michael } \\
\text { W. V. Ormond } \\
\text { R. C. Wayne } \\
\text { D. L. Lindner } \\
\text { G. J. Christensen } \\
\text { C. W. Robinson } \\
\text { W. D. Wilson } \\
\text { J. E. Costa } \\
\text { T. J. Shepodd } \\
\text { M. . Baskes } \\
\text { D. V. Zanini } \\
\text { H. C. Feemster } \\
\text { J. C. F. Wang } \\
\text { T. L. Garner } \\
\text { L. A. Johnston } \\
\text { (n) }\end{array}$ & $\begin{array}{l}8714 \\
8715 \\
8715 \\
8715 \\
8716 \\
8716 \\
8741 \\
8741 \\
8741 \\
8742 \\
8743 \\
8745 \\
8745 \\
8746 \\
8746 \\
8746 \\
8535 \\
8535 \\
7141 \\
8523-2\end{array}$ & $\begin{array}{l}\text { M. W. Perra } \\
\text { D. F. Cowgill } \\
\text { G. J. Thomas } \\
\text { N. Y. C. Yang } \\
\text { J. M. Hruby } \\
\text { D. E. Meeker } \\
\text { G. A. Benedetti } \\
\text { J. C. Keilman } \\
\text { W. P. Trento } \\
\text { P. E. Nielan } \\
\text { M. L. Callabresi } \\
\text { R. J. Kee } \\
\text { W. S. Winters } \\
\text { W. A. Kawahara } \\
\text { B. A. Meyer } \\
\text { J. J. Totten } \\
\text { Technical Communications for } \\
\text { OSTI (10) } \\
\text { Technical Communications/ } \\
\text { Technical Library Processes, } 7141 \\
\text { Technical Library Processes } \\
\text { Department (3) } \\
\text { Central Technical Files (3) }\end{array}$ \\
\hline
\end{tabular}



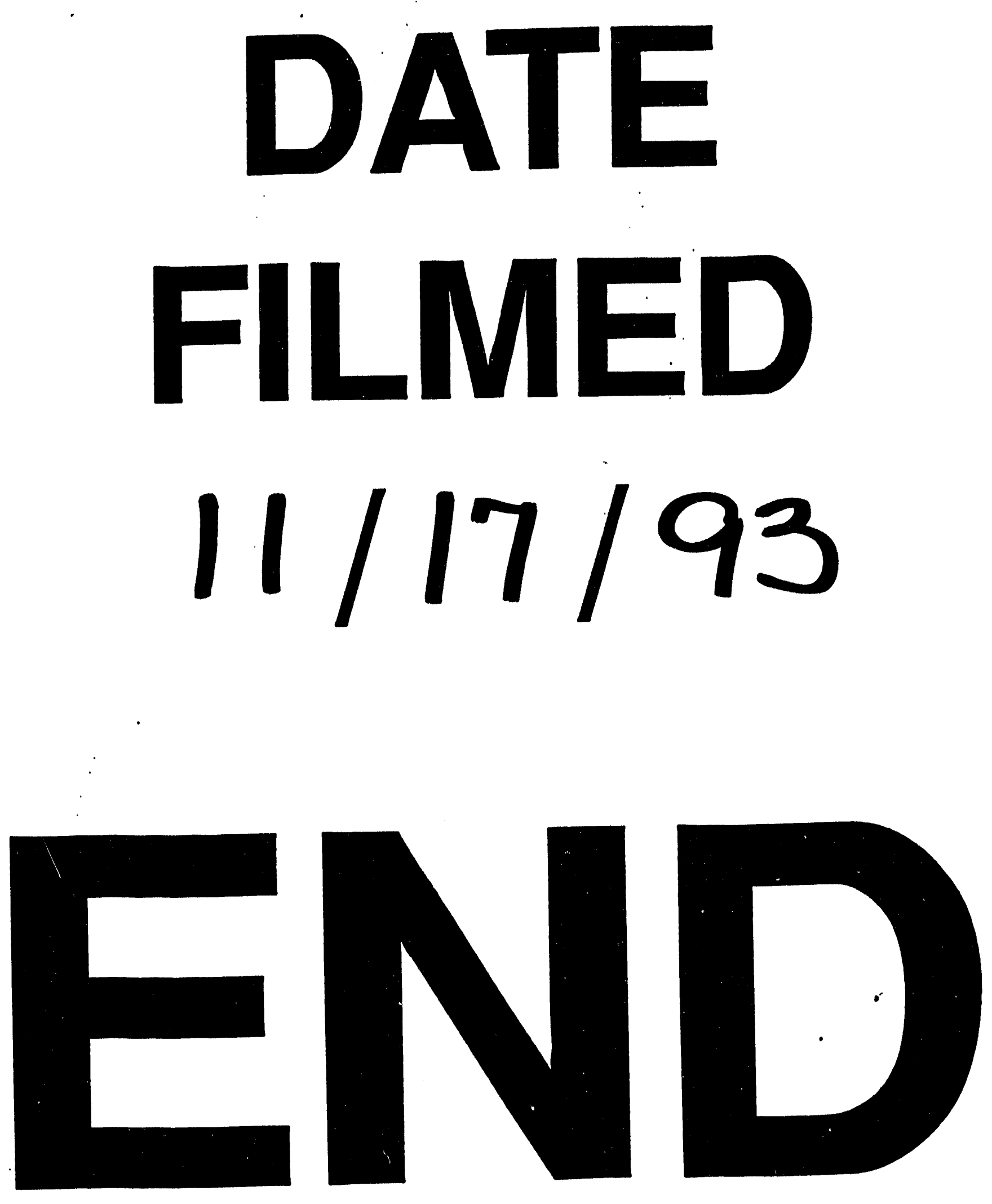
mang 